\title{
Rho-associated kinase inhibitor, Y-27632, inhibits the invasion and proliferation of T24 and 5367 bladder cancer cells
}

\author{
LEI JIANG $^{1}$, JIAMING WEN ${ }^{2}$ and WEI LUO ${ }^{2}$ \\ ${ }^{1}$ Department of Emergency, The Fourth Affiliated Hospital of Zhejiang University School of Medicine, Yiwu, Zhejiang 322000; \\ ${ }^{2}$ Department of Urology, The Second Affiliated Hospital of Zhejiang University School of Medicine, \\ Hangzhou, Zhejiang 310009, P.R. China
}

Received November 20, 2014; Accepted August 17, 2015

DOI: $10.3892 / \mathrm{mmr} .2015 .4404$

\begin{abstract}
The serine/threonine kinases, Rho-associated protein kinase I and II (ROCK I and II), regulate the cytoskeleton by acting downstream of the small GTPase, Rho, and have been implicated in tumorigenesis and cancer metastasis. Inhibition of ROCK signaling has been shown to suppress the invasion and migration of several types of cancer cells. In this study, the effect of the ROCK inhibitor, Y-27632, on the proliferation and invasion of T24 and 5637 bladder cancer cells was investigated. In the proliferation assays, the cells were exposed to $0,10,25,50,75,100,125$ or $150 \mu \mathrm{mol} / 1 \mathrm{Y}-27632$ and proliferation was determined using Cell Counting kit-8 after 24, 48 and $72 \mathrm{~h}$. In the invasion assays, the cells were placed in the upper chamber of transwell plates and subjected to $0,25,50$ or $75 \mu \mathrm{mol} / 1 \mathrm{Y}-27632$ for $24 \mathrm{~h}$, after which invasion was measured. Y-27632 significantly suppressed the cell proliferation of T24 and 5637 cells in a concentration- and time-dependent manner. Y-27632 also inhibited the invasion of T24 and 5637 cells in a concentration-dependent manner $(\mathrm{P}<0.001)$. In addition, $\mathrm{Y}-27632$ suppressed myosin light chain kinase (MLCK) phosphorylation in T24 and 5637 cells, confirming that it is also a downstream effector of the Rho/ROCK pathway in T24 and 5637 bladder cancer cells. In conclusion, the Rho/ROCK/P-MLCK pathway may be important in tumor cell metastasis in bladder cancer.
\end{abstract}

Correspondence to: Dr Wei Luo, Department of Urology, The Second Affiliated Hospital of Zhejiang University School of Medicine, 396 Nanshi Road, Hangzhou, Zhejiang 310009, P.R. China E-mail:180619595@qq.com

Abbreviations: BSA, bovine serum albumin; FBS, fetal bovine serum; MLCK, myosin light chain kinase; ROCK I and II, Rho-associated protein kinase I and II; SD, standard deviation; UBC, urothelial bladder cancer

Key words: bladder cancer, invasion, MLCK, Rho, ROCK

\section{Introduction}

There is significant morbidity and mortality resulting from urothelial bladder cancer (UBC) globally; it is the seventh most common type of cancer in males and the seventeenth in females (1). Smoking and occupational exposure to aromatic amines and polycyclic aromatic hydrocarbons are the most important risk factors for $\operatorname{UBC}(1,2)$. There is significant global variability in the incidence of UBC with the highest rates occurring in Europe, Egypt and the United States, while Asia, South America and Sub-Saharan Africa have the lowest rates (3). Global incidence appears to coincide with the distribution of risk factors (3). Although the majority of cases of UBC are non-invasive at the time of diagnosis, up to $25 \%$ of cases do show different degrees of invasiveness at the time of diagnosis (1). Therefore, understanding the mechanism by which UBCs acquire invasive properties may aid in the identification of novel therapeutic targets.

The Rho/Rho-associated protein kinase (ROCK) pathway has been shown to effect the proliferation and invasion of several types of cancer cells (1-4). Specifically, ROCK is an important molecule in metastasis (4). In addition, the Rho protein is a small GTPase that exhibits a key biological role in cell division and proliferation through its downstream molecules. Furthermore, members of the Rho family of small GTPases regulate microfilament network organization, intercellular contact and malignant transformation (5). They also regulate cytoskeletal activity, and are consequently involved in cellular invasion and migration via epithelial to mesenchymal transition (6). ROCK is the most significant downstream effector of Rho (7), and myosin light chain kinase (MLCK) is a downstream effector of ROCK. The Rho/ROCK/MLCK pathway is important in cell morphology, motility, invasion, adhesion, polarity formation and mitosis, and thus participates in the pathogenesis of cancer (8). Therefore, it is hypothesized that the Rho/ROCK/MLCK pathway may have a role in cancer progression by regulating the reorganization of the actin cytoskeleton. Moreover, ROCK inhibitors, such as Y-27632 (a 4-amino pyridine) have been shown to inhibit the invasion of tumor cells $(9,10)$.

The expression of RhoA and RhoC is significantly higher in bladder cancer cells, suggesting a role in tumorigenesis and invasiveness (11). In 5637 and UM-UC-3 bladder cancer cells, Rho/ROCK signaling increased proliferation and migration, 
Table I. T24 cell proliferation in concentrations of Y-27632 ranging from 0 to $150 \mathrm{mmol} / \mathrm{l}$ at 24,48 and $72 \mathrm{~h}$.

T24 cell proliferation $(\%)$

\begin{tabular}{lccc} 
Y-27632 (mmol/l) & $24 \mathrm{~h}$ & $48 \mathrm{~h}$ & $72 \mathrm{~h}$ \\
\hline 0 & 100 & 100 & 100 \\
10 & $97.39 \pm 1.1$ & $95.3 \pm 1.38^{\mathrm{a}}$ & $93.74 \pm 2.44^{\mathrm{a}}$ \\
25 & $90.72 \pm 1.55^{\mathrm{a}, \mathrm{b}}$ & $87.7 \pm 0.98^{\mathrm{a}, \mathrm{b}}$ & $84.35 \pm 4.27^{\mathrm{a}, \mathrm{b}}$ \\
50 & $84.27 \pm 1.11^{\mathrm{a}-\mathrm{c}}$ & $67.88 \pm 0.9^{\mathrm{a}-\mathrm{c}}$ & $73.32 \pm 2.11^{\mathrm{a}-\mathrm{c}}$ \\
75 & $76.25 \pm 1.89^{\mathrm{a}-\mathrm{d}}$ & $61.73 \pm 1.02^{\mathrm{a}-\mathrm{d}}$ & $60.31 \pm 2.81^{\mathrm{a}-\mathrm{d}}$ \\
100 & $50.83 \pm 1.23^{\mathrm{a}-\mathrm{e}}$ & $47.29 \pm 1.21^{\mathrm{a}-\mathrm{e}}$ & $45.07 \pm 0.9^{\mathrm{a}-\mathrm{e}}$ \\
125 & $45.97 \pm 2.33^{\mathrm{a}-\mathrm{f}}$ & $43.12 \pm 2.03^{\mathrm{a}-\mathrm{f}}$ & $41.26 \pm 1.43^{\mathrm{a}-\mathrm{e}}$ \\
150 & $40.38 \pm 1.38^{\mathrm{a}-\mathrm{g}}$ & $38.81 \pm 1^{\mathrm{a}-\mathrm{g}}$ & $35.22 \pm 1.04^{\mathrm{a}-\mathrm{g}}$ \\
P-value & $<0.001$ & $<0.001$ & $<0.001$
\end{tabular}

$\mathrm{P}<0.05$, significantly different from cells treated with ${ }^{\mathrm{a}} 0,{ }^{\mathrm{b}} 10,{ }^{\mathrm{c}} 5,{ }^{\mathrm{d}} 50,{ }^{\mathrm{e}} 75,{ }^{\mathrm{f}} 100$ and ${ }^{\mathrm{g}} 125 \mathrm{mmol} / \mathrm{l} \mathrm{Y}-27632$. $\mathrm{n}=6$ per group.

and this was inhibited by treatment with the ROCK-specific inhibitor, fasudil (HA-1077) (12). In a similar study, inhibition of the Rho/ROCK pathway by Clostridium difficile toxin B, HA-1077 and Y-27632, inhibited the migration of T24 and J8 bladder cancer cells (13). Also, the inhibition of RhoC by microRNA-493 decreased T24 and J82 bladder cancer cell migration (14). Notably, high expression of Rho/ROCK in patients with bladder cancer is associated with poor tumor differentiation, muscle invasion, and lymph node metastasis (15).

Elements of the Rho/ROCK/MLCK pathway may therefore be therapeutic targets. However, relatively few studies have investigated the effect of the Rho/ROCK pathway on bladder cancer. In the present study, the ROCK inhibitor, Y-27632, was used to investigate the effect of the Rho/ROCK pathway on the proliferation and invasion of T24 and 5634 bladder cancer cells.

\section{Materials and methods}

Cell proliferation assay. T24 and 5637 bladder cancer cell lines were purchased from the Shanghai Institute Cell Bank (Shanghai, China). Cells $\left(1 \times 10^{4}\right.$ cells per well) were seeded in 96-well plates in RPMI-1640 supplemented with $10 \%$ fetal bovine serum (FBS) (both from Gibco-BRL, Carlsbad, CA, USA). Cells were treated with $0,10,25,50,75,100,125$ or $150 \mu \mathrm{mol} / 1 \mathrm{Y}-27632$ (Tocris, Bristol, UK) for 24,48 and $72 \mathrm{~h}$ at $37^{\circ} \mathrm{C}$ with $5 \% \mathrm{CO}_{2}$. At each time point, $10 \mu \mathrm{l}$ Cell Counting kit-8 solution (Dojindo, Kumamoto, Japan) was then added to each well, and the cells were further incubated for $2 \mathrm{~h}$ at $37^{\circ} \mathrm{C}$ with $5 \% \mathrm{CO}_{2}$. Three independent assays were conducted, and the average was taken.

Cell invasion assay. Transwell chambers (5- $\mu \mathrm{m}$ pore size; Corning, NY, USA) were pre-coated with BD Matrigel ${ }^{\mathrm{TM}}$ (BD Biosciences, San Jose, CA, USA) according to the manufacturer's instructions. The cells were harvested and resuspended in media containing FBS, and $200 \mu \mathrm{l}$ of the suspension containing $5 \times 10^{4}$ cells was added to the upper chamber. The cells were then treated with $0,25,50$ or $75 \mu \mathrm{mol} / 1 \mathrm{Y}-27632$, and incubated for $24 \mathrm{~h}$ at $37^{\circ} \mathrm{C}$. The transwells were removed and stained with crystal violet (Sigma-Aldrich, St. Louis, MO, USA) and the cells in the lower partition were counted under a light microscope (GX41; Olympus, Tokyo, Japan) at x200. The percentage of inhibition was calculated according to the following formula: Percentage inhibition $=($ control group penetrated cells-experimental group penetrated cells) / control group penetrating cells x 100 .

Western blot analysis. Cells were treated with various concentrations of Y-27632 then harvested and lysed in lysis buffer (Thermo Fisher Scientific, Waltham, MA, USA). After $50 \mu \mathrm{g}$ of protein was separated by $7.5 \%$ SDS-PAGE $(7.5 \%$ Mini-Protean TGX ${ }^{\mathrm{TM}}$ Precast Protein gels; Bio-Rad, Hercules, CA, USA) and transferred onto nitrocellulose membranes (EMD Millipore, Billerica, MA, USA), the membranes were blocked with $5 \%$ bovine serum albumin (Sigma-Aldrich) in Tris-buffered saline for $60 \mathrm{~min}$ and washed three times. The membranes were then incubated with monoclonal rabbit antihuman antibodies against P-MLCK (1:1,000; cat. no. ab76092; Abcam, Cambridge, UK) or polyclonal rabbit anti-human antibodies against $\beta$-actin $(1: 1,000$; cat. no. A2668; SigmaAldrich) at $4^{\circ} \mathrm{C}$ overnight, and then with polyclonal goat anti-rabbit horseradish peroxidase-conjugated secondary antibody (1:3,000; Zhongshan Golden Bridge Biotechnology Co., Beijing, China) at room temperature for $60 \mathrm{~min}$. NIH Image J analysis software V.1 (National Institutes of Health, Bethesda, MD, USA) was used to detect the optical density of P-MLCK bands, and was normalized to the values obtained for $\beta$-actin to determine the relative expression of P-MLCK.

Statistical analysis. Continuous variables was presented as the mean \pm standard deviation. Repeated measurement analysis of variance (ANOVA) with Bonferroni post hoc tests were performed to compare the differences between different time points at each concentration of Y-27632 in T24 and 5637 cell proliferation assays. One-way ANOVA with Bonferroni post hoc tests were performed to compare the differences among the different concentrations of Y-27632 in T24 and 5637 cell proliferation, cell count, and inhibition rate at each 
Table II. 5637 cell proliferation in concentrations of Y-27632 ranging from 0 to $150 \mathrm{mmol} / \mathrm{l}$ at 24, 48, and $72 \mathrm{~h}$.

\begin{tabular}{|c|c|c|c|}
\hline \multirow[b]{2}{*}{ Y-27632 (mmol/l) } & \multicolumn{3}{|c|}{5637 cell proliferation $(\%)$} \\
\hline & $24 \mathrm{~h}$ & $48 \mathrm{~h}$ & $72 \mathrm{~h}$ \\
\hline 0 & 100 & 100 & 100 \\
\hline 10 & $97.7 \pm 1.33$ & $95.39 \pm 3.68$ & $92.37 \pm 0.71^{\mathrm{a}}$ \\
\hline 25 & $92.36 \pm 1.16^{\mathrm{a}, \mathrm{b}}$ & $90.49 \pm 3.51^{\mathrm{a}, \mathrm{b}}$ & $85.3 \pm 0.63^{\mathrm{a}, \mathrm{b}}$ \\
\hline 50 & $86.9 \pm 2.27^{\mathrm{a}-\mathrm{c}}$ & $80.64 \pm 3.01^{\mathrm{a}-\mathrm{c}}$ & $78.72 \pm 0.57^{\mathrm{a}-\mathrm{c}}$ \\
\hline 75 & $75.02 \pm 1.47^{\mathrm{a}-\mathrm{d}}$ & $69.32 \pm 2.8^{\mathrm{a}-\mathrm{d}}$ & $66.3 \pm 0.53^{\mathrm{a}-\mathrm{d}}$ \\
\hline 100 & $49.8 \pm 0.86^{\mathrm{a}-\mathrm{e}}$ & $43.06 \pm 1.23^{\mathrm{a}-\mathrm{e}}$ & $41.2 \pm 0.27^{\mathrm{a}-\mathrm{e}}$ \\
\hline 125 & $40.32 \pm 1.49^{\mathrm{a}-\mathrm{f}}$ & $38.63 \pm 1.83^{\mathrm{a}-\mathrm{e}}$ & $36.12 \pm 0.48^{\mathrm{a}-\mathrm{f}}$ \\
\hline 150 & $35.2 \pm 1.36^{\mathrm{a}-\mathrm{g}}$ & $33.4 \pm 1.18^{\mathrm{a}-\mathrm{g}}$ & $31.56 \pm 0.56^{\mathrm{a}-\mathrm{g}}$ \\
\hline P-value & $<0.001$ & $<0.001$ & $<0.001$ \\
\hline
\end{tabular}

$\mathrm{P}<0.05$, significantly different from cells treated with ${ }^{\mathrm{a}} 0,{ }^{\mathrm{b}} 10,{ }^{\mathrm{c}} 25,{ }^{\mathrm{d}} 50,{ }^{\mathrm{e}} 75,{ }^{\mathrm{f}} 100$, and ${ }^{\mathrm{g}} 125 \mathrm{mmol} / \mathrm{l} \mathrm{Y}-27632 . \mathrm{n}=6 /$ group.

A

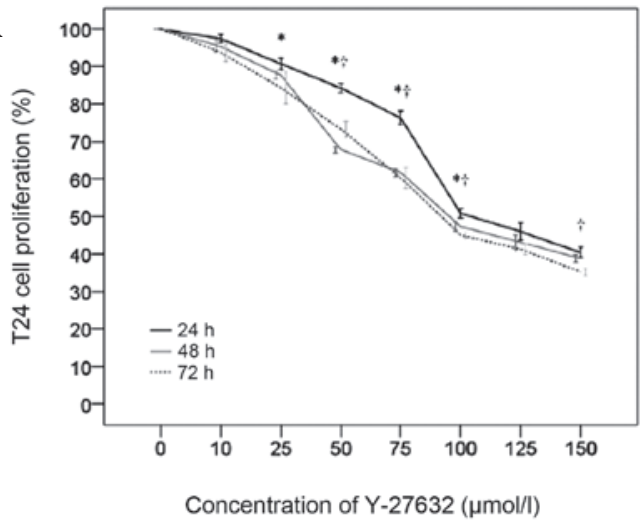

B

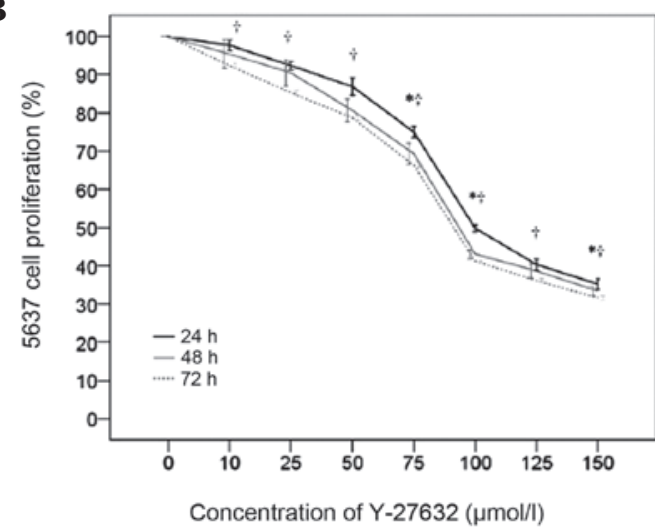

Figure 1. Effect of Y-27632 on bladder cancer cell proliferation. (A) T24 and (B) 5637 cell proliferation was determined using the Cell Counting kit-8 assay. ${ }^{*} \mathrm{P}<0.05$, compared with $48 \mathrm{~h}$ or ${ }^{\dagger} \mathrm{P}<0.05$, compared with $72 \mathrm{~h}$.

time point. $\mathrm{P}<0.05$ was considered to indicate a statistically significant difference. SPSS 17.0 statistics software (SPSS Inc., Chicago, IL, USA) was used for the statistical analyses.

\section{Results}

Effect of Y-27632 on T24 and 5637 cell proliferation. T24 and 5637 bladder cancer cells were subjected to Y-27632 concen-

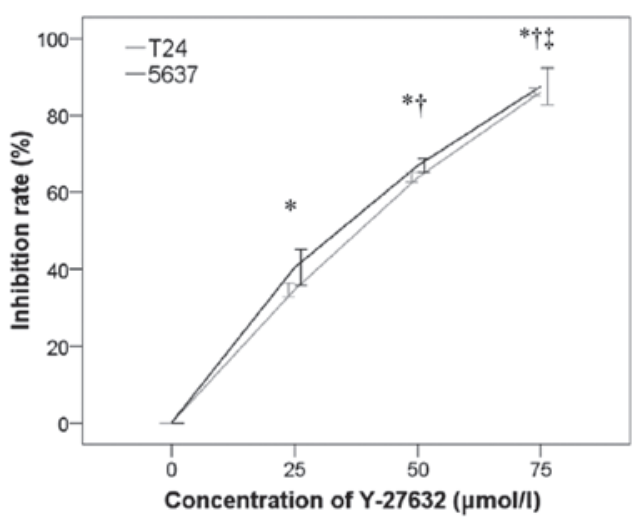

Figure 2. Comparison of the rate of inhibition of T24 and 5637 cell proliferation by different concentrations of $\mathrm{Y}-27632{ }^{*} \mathrm{P}<0.05$, compared with $0 \mu \mathrm{mol} / \mathrm{l}$; ${ }^{\dagger} \mathrm{P}<0.05$, compared with $25 \mu \mathrm{mol} / 1$ and ${ }^{\ddagger} \mathrm{P}<0.05$, compared with $50 \mu \mathrm{mol} / 1$.

tration-response and time course assays. Y-27632 significantly suppressed the cell proliferation of T24 and 5637 cells in a concentration-dependent manner (Fig. 1, Tables I and II). At $24 \mathrm{~h}$, the proliferation of T24 cells significantly decreased from 0 to $150 \mu \mathrm{mol} / 1 \mathrm{Y}-27632(\mathrm{P}<0.001)$. Similar decreases in T24 cell proliferation were observed at 48 and $72 \mathrm{~h}$ (Table I). In addition, $\mathrm{T} 24$ cell proliferation decreased significantly with time from 0 to $72 \mathrm{~h}$ (Fig. 1A). At $24 \mathrm{~h}$, the proliferation of 5637 cells decreased significantly from 0 to $150 \mu \mathrm{mol} / 1(\mathrm{P}<0.015)$. Similar decreases in 5637 cell proliferation were observed at 48 and $72 \mathrm{~h}$ (Table II).

Effect of Y-27632 on T24 and 5637 cell invasion. Y-27632 inhibited the invasion of T24 and 5637 cells in a concentration-dependent manner ( $\mathrm{P}<0.001$; Fig. 2). At $24 \mathrm{~h}$, the inhibition of cellular invasion increased significantly with increasing concentrations of Y-27632. Representative images from the invasion assays are shown in Fig. 3.

Suppression of P-MLCK expression by $Y-27632$ in $T 24$ and 5637 cells. MLCK is a known downstream effector of the Rho/ROCK pathway in several cells. Therefore, P-MLCK 

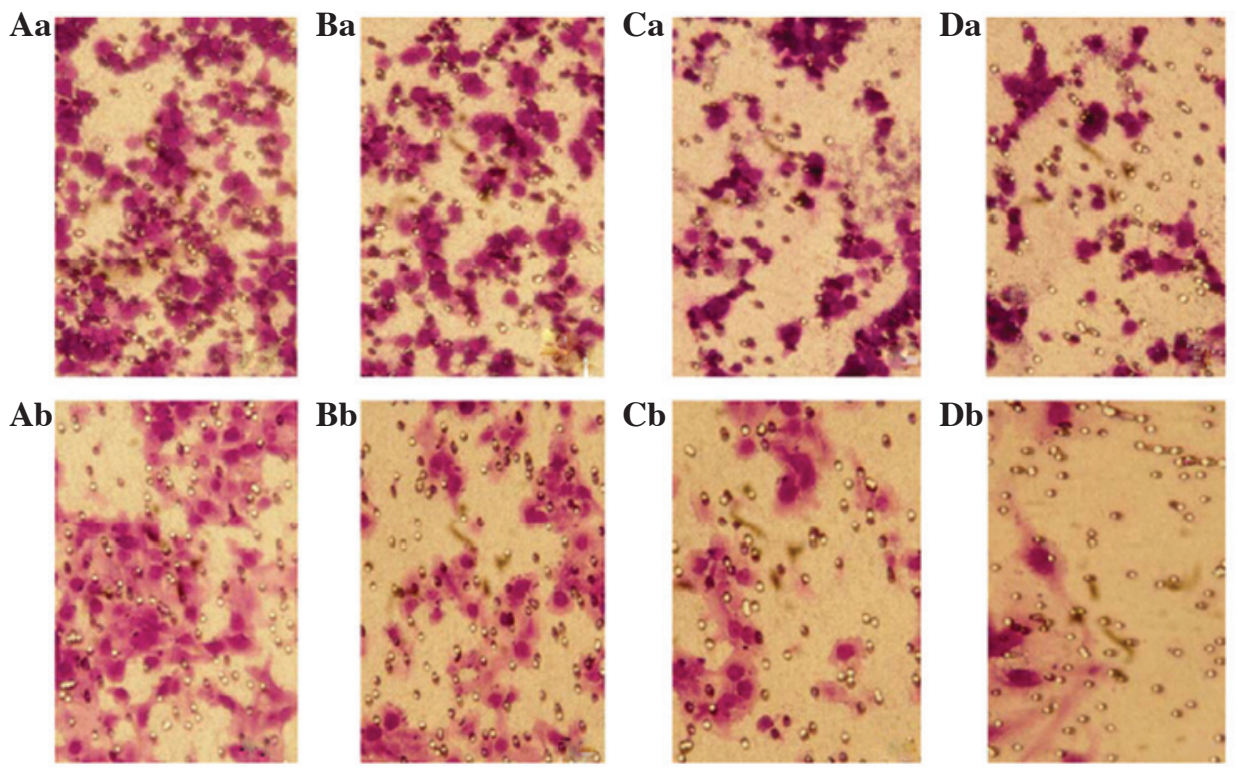

Figure 3. Effect of Y-27632 on bladder cancer cell invasion. Invasive T24 cells (top panels) and 5637 cells (bottom panels) were stained with crystal violet after they were treated with 0 ( $\mathrm{Aa}$ and $\mathrm{Ab}$ ), 25 ( $\mathrm{Ba}$ and $\mathrm{Bb}$ ), 50 (Ca and $\mathrm{Cb}$ ) and 75 ( $\mathrm{Da}$ and $\mathrm{Db}$ ) mmol/1 Y-27632. x200 magnification.

A
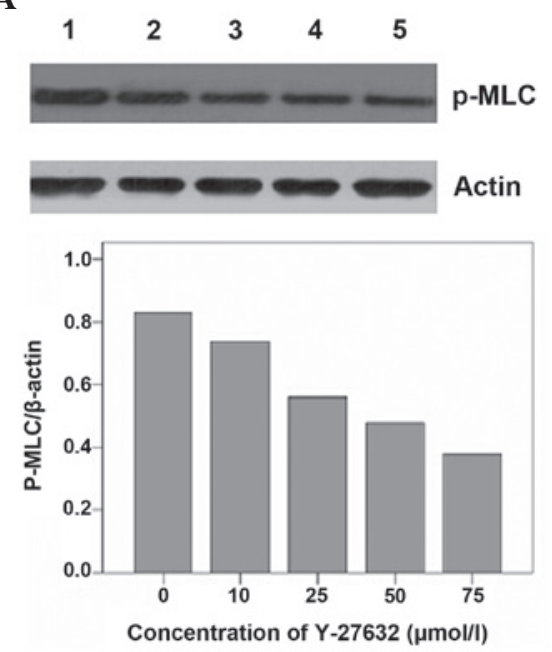

B

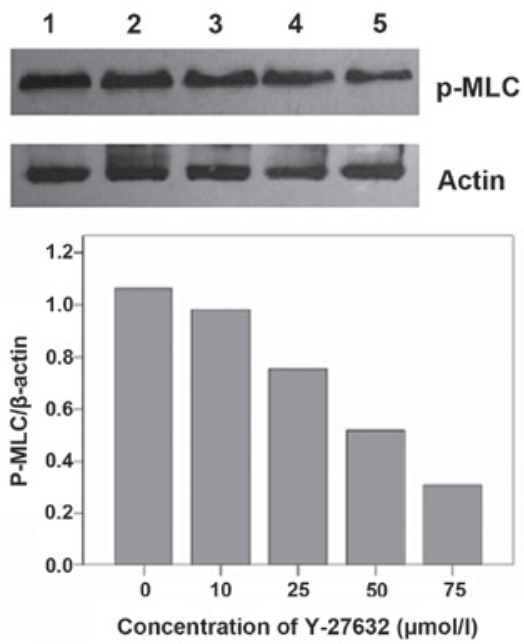

Figure 4. Effect of Y-27632 on MLCK phosphorylation. The ratio of P-MLCK/ $\beta$-actin, in (A) T24 cells and (B) 5637 cells after incubation with different concentrations of Y-27632. MLCK, myosin light chain kinase; P-MCLK, phosphorylated-MCLK.

protein levels were assessed in response to various concentrations of Y-27632 by western blot analysis. As shown in Fig. 4, Y-27632 suppressed P-MLCK protein expression in T24 and 5637 cells, confirming that it is also a downstream effector of the Rho/ROCK pathway in T24 and 5637 bladder cancer cells.

\section{Discussion}

Evidence from several studies indicates that signaling pathways downstream of Rho GTPases are vital in tumor development and progression $(16,17)$. Consequently, there has been considerable interest in the possibility that specific proteins in the Rho/ROCK signal transduction pathway could represent potential cancer therapeutic targets. Relatively little investigation has been conducted, however, regarding the transduction mechanisms of the Rho/ROCK pathway in bladder cancer.
The Rho/ROCK signal transduction mechanisms shown in other types of cancers could be common to all types of cancer or idiosyncratic to the cancer types investigated. It is, therefore, important to study these mechanisms in bladder cancer to generate a knowledge base for the potential development of bladder cancer-specific, Rho pathway-derived, therapeutic targets. In the present study, it was demonstrated that Y-27632 inhibited T24 and 5637 cell proliferation and invasion in a concentration-dependent manner. It also suppressed MLCK phosphorylation in T24 and 5637 cells.

In this study, the specific ROCK inhibitor, Y-27632, was used to compare proliferation and invasion of bladder cancer cells when the Rho/ROCK pathway was inhibited by increasing concentrations of Y-27632. Cell proliferation of the T24 and 5637 cancer cell lines was inhibited by Y-2763 in a concentration-dependent manner. The inhibition of bladder cancer cell 
proliferation by Y-27632 is in contrast to what has been reported of non-tumor cells. For example, Horani et al (18) reported an increase in airway epithelial basal cell proliferation upon Rho inhibition, and Yu et al (19) also reported an increase in astrocyte proliferation upon inhibiting ROCK with Y-27632. The fact that inhibition of the Rho/ROCK pathway inhibits bladder cell proliferation while sparing or enhancing the proliferation of normal tissues renders the proteins in this pathway an attractive therapeutic target in bladder cancer. However, further studies are required to assess the mechanism by which Y-27632 alters bladder cancer proliferation as well as assess its effects in vivo.

ROCK is a serine/threonine protein kinase that is an important downstream target of Rho. It is involved in several biological activities, including cell adhesion, mitosis, cytoskeletal reorganization, muscle cell contraction, and invasion of tumor cells (20). It was also demonstrated that inhibition of ROCK by Y-27632 suppressed T24 and 5637 cell invasion. The inhibition of invasion was concentration-dependent and in agreement with the findings of other groups. For example, Huang et al (21) reported the inhibition of TSGH urothelial cancer cell invasion upon inhibiting ROCK with Y-27632, and Imamura et al (10) reported a similar effect with ascites hepatoma cells.

ROCK performs these biological functions by phosphorylating a variety of downstream substrates, including MLCK, connexin and LIM kinase (22-24). Therefore, MLCK was investigated as a possible downstream effector. Y-27632 inhibited the phosphorylation of MLCK in a concentration-dependent manner, indicating that MLCK is a downstream effector of the Rho/ROCK pathway for the enhancement of proliferation and invasion in these bladder cancer cells. This expands the number of potential bladder cancer therapeutic targets in the Rho/ROCK pathway. However, further studies are required to analyze whether the inhibition of bladder cancer cell proliferation and invasion by Y-27632 was mediated by its effect on MLCK phosphorylation.

This study was limited in its scope as it investigated the effects of Y-27632 on in vitro cell proliferation and invasion only. Thus, further in vivo studies are warranted to confirm these findings as well as uncover the underlying mechanism. In addition, the expression of these proteins may be analyzed in bladder cancer samples isolated from patients to determine the prognostic value of analyzing this pathway.

In conclusion, this study showed that T24 and 5637 bladder cancer cell proliferation and invasion were inhibited with the Rho kinase inhibitor, Y-27632. Furthermore, Y-27632 suppressed P-MLCK protein expression in T24 and 5637 cells. Thus, the Rho/ROCK/P-MLCK pathway may be important in tumor cell metastasis in bladder cancer.

\section{References}

1. Burger M, Catto JW, Dalbagni G, Grossman HB, Herr H, Karakiewicz P, Kassouf W, Kiemeney LA, La Vecchia C, Shariat S and Lotan Y: Epidemiology and risk factors of urothelialbladder cancer. Eur Urol 63: 234-241, 2013.

2. Ferreccio C, Yuan Y, Calle J, Benítez H, Parra RL, Acevedo J, Smith AH, Liaw J and Steinmaus C: Arsenic, tobacco smoke and occupation: Associations of multiple agents with lung and bladder cancer. Epidemiology 24: 898-905, 2013.

3. Chavan S, Bray F, Lortet-Tieulent J, Goodman M and Jemal A: International variations in bladder cancer incidence and mortality. Eur Urol 66: 59-73, 2014.
4. Somlyo AP and Somlyo AV: $\mathrm{Ca}^{2+}$ sensitivity of smooth muscle and nonmuscle myosin II: Modulated by G proteins, kinases and myosin phosphatase. Physiol Rev 83: 1325-1358, 2003.

5. Hall A: Rho GTPases and the actin cytoskeleton. Science 279: 509-514, 1998.

6. Gómez del Pulgar T, Benitah SA, Valerón PF, Espina C and Lacal JC: Rho GTPase expression in tumourigenesis: Evidence for a significant link. Bioessays 27: 602-613,2005.

7. Matsui T, Amano M, Yamamoto T, Chihara K, Nakafuku M, Ito M, Nakano T, Okawa K, Iwamatsu A and Kaibuchi K: Rho-associated kinase, a novel serine/threonine kinase, as a putative target for small GTP binding protein Rho. EMBO J 15: 2208-2216, 1996.

8. Duan WG, Yuan ST, Liao H, Yan M and Zhang LY: Advances in the study of Rho kinase and its inhibitors. Yao Xue Xue Bao 42: 1013-1022, 2007 (In Chinese).

9. Itoh K, Yoshioka K, Akedo H, Uehata M, Ishizaki T and Narumiya S: An essential part for Rho-associated kinase in the transcellular invasion of tumor cells. Nat Med 5: 221-225, 1999.

10. Imamura F, Mukai M, Ayaki M and Akedo H: Y-27632, an inhibitor of rho-associated protein kinase, suppresses tumor cell invasion via regulation of focal adhesion and focal adhesion kinase. Jpn J Cancer Res 91: 811-816, 2000.

11. Volanis D, Zaravinos A, Kadiyska T, Delakas D, Zoumpourlis V and Spandidos DA: Expression profile of Rho kinases in urinary bladder cancer. J BUON 16: 511-521, 2011.

12. Abe H, Kamai T, Hayashi K, Anzai N, Shirataki H, Mizuno T, Yamaguchi Y, Masuda A, Yuki H, Betsunoh $\mathrm{H}$, et al: The Rho-kinase inhibitor HA-1077 suppresses proliferation/migration and induces apoptosis of urothelial cancer cells. BMC Cancer 14: 412, 2014

13. von Dorp F, Sanders H, Boergermann C, Lümmen G, Rübben H, Jakobs KH and Schmidt M: Inhibition of Rho-kinase abrogates migration of human transitional cell carcinoma cells: Results of an in vitro study. Urol Int 86: 220-227, 2011.

14. Ueno K, Hirata H, Majid S, Yamamura S, Shahryari V, Tabatabai ZL, Hinoda Y and Dahiya R: Tumor suppressor microRNA-493 decreases cell motility and migration ability in human bladder cancer cells by downregulating RhoC and FZD4. Mol Cancer Ther 11: 244-253, 2012.

15. Kamai T, Tsujii T, Arai K, Takagi K, Asami H, Ito $\mathrm{Y}$ and Oshima H: Significant association of Rho/ROCK pathway with invasion and metastasis of bladder cancer. Clin Cancer Res 9: 2632-2641, 2003.

16. Rösel D, Brábek J, Tolde O, Mierke CT, Zitterbart DP, Raupach C, Bicanová K, Kollmannsberger P, Panková D, Vesely P, et al: Up-regulation of Rho/ROCK signaling in sarcoma cells drives invasion and increased generation of protrusive forces. Mol Cancer Res 6: 1410-1420, 2008

17. Ying H, Biroc SL, Li WW, Alicke B, Xuan JA, Pagila R, Ohashi Y, Okada T, Kamata Y and Dinter H: The Rho kinase inhibitor fasudil inhibits tumor progression in human and rat tumor models. Mol Cancer Ther 5: 2158-2164, 2006.

18. Horani A, Nath A, Wasserman MG, Huang T and Brody SL: Rho-associated protein kinase inhibition enhances airway epithelial Basal-cell proliferation and lentivirus transduction. Am J Respir Cell Mol Biol 49: 341-347, 2013.

19. Yu Z, Liu M, Fu P, Xie M, Wang W and Luo X: ROCK inhibition with Y27632 promotes the proliferation and cell cycle progression of cultured astrocyte from spinal cord. Neurochem Int 61: 1114-1120, 2012.

20. Mueller BK, Mack H and Teusch N: Rho kinase, a promising drug target for neurological disorders. Nat Rev Drug Discov 4: 387-398, 2005

21. Huang HP, Wang CJ, Tsai JP, Wu SW, Hung TW, Lian JD and Chang HR: Y27632 attenuates the aristolochic acid-promoted invasion and migration of human urothelial cancer TSGH cells in vitro and inhibits the growth of xenografts in vivo. Nephrol Dial Transplant 27: 565-575, 2012.

22. Heneweer C, Kruse LH, Kindhäuser F, Schmidt M, Jakobs KH, Denker $\mathrm{H}$ and Thie M: Adhesiveness of human uterine epithelial RL95-2 cells to trophoblast: Rho protein regulation. Mol Hum Reprod 8: 1014-1022, 2002.

23. Fukata M, Nakagawa M and Kaibuchi K: Roles of Rho-family GTPases in cell polarisation and directional migration. Curr Opin Cell Biol 15: 590-597, 2003.

24. Song Y, Hoang BQ and Chang DD: ROCK-II-induced membrane blebbing and chromatin condensation require actin cytoskeleton. Exp Cell Res 278: 452-521, 2002. 